\title{
PENGARUH KOMUNIKASI INTERNAL ORGANISASI TERHADAP MOTIVASI KERJA PEGAWAI BIRO HUMAS KEMENTERIAN PERINDUSTRIAN
}

\author{
${ }^{1}$ Risky Anis Safitri, ${ }^{2}$ Baby Taszya Risaldi, ${ }^{3}$ Malinda Oktaviani \\ 1,2,3 Program Studi Ilmu Komunikasi STIKOM The London School of Public Relations \\ Email: riskyanissafitri@gmail.com
}

\begin{abstract}
Abstrak
Komunikasi diperlukan di dalam suatu organisasi. Untuk membangun motivasi kerja pegawai harus dimulai dengan menciptakan komunikasi internal yang baik. Tujuan dari penelitian ini adalah untuk mengetahui ada atau tidaknya pengaruh komunikasi internal tehadap motivasi kerja pegawai Biro Humas Kementerian Perindustrian dan seberapa besar pengaruh komunikasi internal tehadap motivasi kerja pegawai Biro Humas Kementerian Perindustrian. Penelitian ini menggunakan metode kuantitatif. Jumlah sampel dalam penelitian ini adalah 57 responden dengan 21 pertanyaan pada kuesioner. Hasil penelitian ini menunjukan bahwa komunikasi internal memiliki pengaruh yang signifikan terhadap motivasi kerja pegawai. Persamaan yang didapat adalah $Y=0,509+0,922 X$. Variable X mengacu pada komunikasi internal dan variable Y mengacu pada motivasi kerja. Setelah diolah, dihasilkan nilai (r) sebesar 0,748 menunjukan adanya hubungan positif yang kuat. Kontribusi pengaruh komunikasi internal terhadap motivasi kerja pegawai sebesar $56 \%$ sisanya $44 \%$ dipengaruhi oleh variable yang tidak diteliti.
\end{abstract}

Kata Kunci : komunikasi organisasi; komunikasi internal; motivasi kerja

\begin{abstract}
Communication is required within an organization. Building employee motivation must begin by creating good internal communication. The purpose of this research to know if there is any Influence of Internal Communication on Employee's Work Motivation in Public Relations Bureau Ministry of industry and to know how much Influence there is on Internal Communication on Employee's Work Motivation in Public Relations Bereau Ministry of industry. This research uses quantitative method. The number of samples in this study are 57 respondents with 21 questions on the questionnaire. The results of this study indicate that internal communication has a significant effect on employee work motivation. The obtained equation is $Y=0,509+0,922 X$. Variable $X$ refers to internal communication and variable $Y$ refers to work motivation. After the data processing, the resulting value ( $r$ ) of 0.748 indicates a strong positive relationship. Contribution of the influence of internal communication to employee motivation by $56 \%$ the remaining $44 \%$ influenced by the variable not examined.
\end{abstract}

Keywords: Organizational communication, internal communication, and work motivation.

\section{PENDAHULUAN}

Di era masyarakat global saat ini sumber daya manusia merupakan asset penting bagi instansi pemerintah. Sumber daya manusia ini mempengaruhi keberhasilan karena mempengaruhi sumber daya lainya. Di dalam setiap perusahaan pasti menginginkan seluruh karyawanya dapat bekerja dan memberikan kontribusi yang positif sesuai dengan yang diharapkan. Untuk mencapai tujuan perusahaan dibutuhkan motivasi untuk dapat 
mempertahankan kualitas daripada pegawai di suatu perusahaan. Motivasi menurut Hill dan Mcshane (dalam Kaswan, 2008:155) merupakan proses yang menjelaskan insentitas, arah, dan ketekunan seorang individu dalam mencapai tujuanya. Maka dari itu motivasi menjadi hal yang dapat dipertimbangkan untuk dijaga dan diperhatikan.

Motivasi kerja pegawai tidak selalu dalam kondisi baik. Oleh karena itu diperlukan adanya upaya untuk meningkatkan motivasi kerja. Menurut Glaser (dalam Ariyani, 2013:4) pada dasarnya manusia atau seseorang yang berada pada kehidupan organisasi berusaha untuk menentukan dan membentuk suatu rancangan aktivitas semua pihak, agar menjalankan aktivitas tidak berbenturan dengan aktivitas tersebut seperti lingkungan, budaya , kepercayaan, nilai, dan harapan. Mereka mempengaruhi dan dipengaruhi oleh konteks atau lingkungan mereka.

Meningkatkan motivasi kerja pegawai bisa dilakukan dengan adanya interaksi kerja dan lingkungan kerja yang kondusif. Membangun komunikasi merupakan salah satu cara untuk membangun lingkungan yang baik. Dengan membangun komunikasi maka informasi yang didapatkan juga semakin luas dan beragam. Hal itu dikarenakan komunikasi merupakan proses pembagian dan pertukaran ide, informasi, pengetahuan, sikap, atau perasaan antara individu dan kelompok yang bertujuan untuk menciptakan suatu aktifitas (Liliweri, 2011, p. 37). Komunikasi (Usman, 2013, p. 1) juga dapat memelihara motivasi di dalam suatu organisasi dengan memberikan penjelasan kepada para pegawai tentang apa yang harus dilakukan, seberapa baik mereka melakukan pekerjaan dan apa yang dapat mereka lakukan untuk meningkatkan motivasi kerja jika sedang berada di bawah standar. Giri dan Kumar (dalam Effendi, 2016:27) menambahkan bahwa komunikasi merupakan hal yang utama yang dilihat dalam memahami bagaimana sebuah organisasi dan beperan penting dalam perkembanganya. Semakin baik komunikasi yang berlangsung di dalam suatu instansi atau perusahaan maka semakin dekat dengan tujuan. Efektivitas komunikasi . Inilah yang sebernarnya diinginkan oleh suatu perusahaan.

Maka dari itu proses komunikasi yang terjadi penting dan menarik untuk diberi perhatian lebih terutama di dalam suatu organisasi. Komunikasi organisasi menurut Zelko dan Dance (dikutip dalam Mokodompit, 2013:3) merupakan suatu sistem yang saling bergantung yang mencakup komunikasi internal dan eksternal.

Komunikasi internal menurut muhammad (dikutip dalam Astuti, Bagia, \& Susila, 2016:2) adalah komunikasi yang dikirimkan kepada anggota dalam suatu organisasi. Maka dari itu penerima pesan dalam komunikasi internal merupakan orang-orang yang berada di dalam organisasi tersebut. Didalam komunikasi internal organisasi (dikutip dalam Mokodompit, 2013:3) kita berbicara tentang arah aliran informasi yang berpindah secara formal dari seorang yang otoritasnya lebih tinggi kepada orang lain yang otoritasnya lebih rendah (komunikasi kebawah). Kemudian informasi yang bergerak dari suatu jabatan yang otoritasnya lebih rendah kepada orang yang otoritasnya lebih tinggi (komunikasi keatas). Terakhir, informasi yang bergerak diantara orang-orang yang jabatanya sama tingkat otoritasnya (komunikasi horizontal).

Pentingnya komunikasi internal organisasi menurut Effendy (dikutip dalam Ruliana, 2016:101) komunikasi internal itu sendiri terjadi dalam suatu organisasi yang menyangkut publik internal. Publik internal sendiri merupakan seluruh karyawan yang terdapat di dalam 
suatu perusahaan atau organisasi. Hal ini yang menyebabkan bahwasanya komunikasi internal menyangkut seluruh sumber daya terbesar di dalam organisasi.

Dalam Penelitian ini, peneliti mengambil studi penelitian pada Kementerian Perindustrian. Kementerian perindustrian merupakan suatu instansi pemerintah (Kementerian Perindustrian, n.d.) yang memiliki tugas untuk menyelenggarakan urusan di bidang perindustrian dalam pemerintahan untuk membantu presiden dalam menyelenggarakan pemerintahan negara. Biro Hubungan Masyarakat (Kementerian Perindustrian) sendiri memiliki tugas untuk melaksanakan pembinaan, koordinasi. Pemberian dukungan administrasi masyarakat dan kerja sama.

\section{Tabel 1. Rekap Absensi Pegawai Biro Hubungan Masyarakat Periode 1 September - 31 Desember 2017}

\begin{tabular}{ccccccccccc}
\hline$<$ & $07: 30$ & $>$ & Pulang & Dina & Total & Sa & & Cut & & \\
07:30 & - & $09: 00$ & Cepat & $\begin{array}{c}\text { s } \\
\text { Luar }\end{array}$ & Hadir & kit & & I & TB & Alpa \\
$30 \%$ & $24 \%$ & $6 \%$ & $1 \%$ & $25 \%$ & $85 \%$ & $\begin{array}{c}3 \\
0\end{array}$ & $1 \%$ & $4 \%$ & $5 \%$ & $3 \%$ \\
\hline
\end{tabular}

Sumber : Kementerian Perindustrian, 2017

Berdasarkan Pre-research yang peneliti lakukan dalam waktu 3 bulan terhitung mulai dari 12 September 2017 sampai dengan 12 Desember 2017 dimana peneliti mengikuti aktivitas yang terjadi di dalam Biro Humas Kementerian Perindustrian. Peneliti melihat bahwa di dalam Kementerian Perindustrian ditemukan beberapa gejala yang mengindikasikan rendahnya motivas kerja pegawai diantaranya pegawai sering telambat hadir bekerja seperti yang terlihat pada tabel 1. Pada periode september 2017 sampai dengan desember 2017 masih ada sekitar $30 \%$ pegawai yang terlambat dalam absen bekerja atau datanng melebihi jam masuk ( jadwal masuk absen maksimal adalah < 7.30 selain itu dianggap terlambat) Padahal menurut Sarwoni (Sari \& Nurdin, 2016:92) absensi pegawai dapat menjadi dasar pengukuran motivasi. Semakin banyak pegawai yang terlambat absen maka semakin rendah pula motivasi mereka dalam menjalankan pekerjaan.

Hal tersebut juga didukung oleh jurnal (Sari \& Nurdin, 2016:92) yang berjudul "pengaruh komunikasi internal organisasi terhadap motivasi kerja". Pada penelitian yang mereka lakukan terdapat hasil bahwa adanya hubungan antara komunikasi internal terhadap motivasi kerja dan juga terdapat pengaruh yang positif dan signifikan dari komunikasi internal terhadap motivasi kerja pegawai.

Oleh karena itu dari pemaparan diatas peneliti tertarik ingin melihat lebih jauh komunikasi yang terjadi antara Kepala Sub bagian (KasSubBag/ Kabid) dengan staffnya baik antara komunikasi atasan ke bawahan, maupun bawahan ke atasan. Melihat adanya pengaruh yang penting antara komunikasi internal Organisasi terhadap kinerja pegawai. Maka penulis mengambil judul "Pengaruh Komunikasi Internal Organisasi Terhadap Motivasi Kerja Pegawai Kementerian Perindustrian (Kabid)". 
Berdasarkan latar belakang diatas maka perumusan masalah yang dapat dikemukakan adalah "Apakah Terdapat Pengaruh Komunikasi Internal Organisasi Terhadap Motivasi Kerja Pegawai Biro Humas Kementerian Perindustrian?”. Penelitian ini memiliki tujuan yaitu sebagai berikut (1) |Untuk mengetahui ada atau tidaknya Pengaruh Komunikasi Internal Organisasi terhadap Motivasi Kerja pegawai Biro Humas Kementerian Perindustrian ( Kabid dan staff). (2) Untuk mengetahui seberapa besar Pengaruh Komunikasi Internal Organisasi terhadap Motivasi Kerja Pegawai Biro Humas Kementerian Perindustrian ( Kabid dan staff).

\section{Komunikasi Organisasi}

Menurut R. Wayne Pace dan Don F (dalam Ruliana, 2016:25) definisi fungsional dari komunikasi organisasi sebagai pertunjukan dan penafsiran pesan di antara unit-unit komunikasi yang merupakan bagian dari suatu organisasi tertentu. Suatu organisai, dengan demikian, terdiri dari unit- unit komunikasi dalam hubungan hierarki antara yang satu dengan yang lainnya dan berfungsi dalam suatu lingkungan.

Menurut Liliweri (2014:372) ada empat tujuan komunikasi organisasi. Pertama, Menyatakan pikiran, pandangan, dan pendapat. Memberi peluang bagi para pemimpin organisasi dan anggotanya untuk menyatakan pikiran, padangan, dan pendapat sehubungan dengan tugas dan fungsi yang mereka lakukan. Kedua, Membagi informasi. Memberi peluang kepada seluruh apartur organisasi untuk membagi informasi dan memberi makna yang sama atas visi, misi, tugas pokok, fungsi organisasi, sub-organisasi, individu, maupun kelompok kerja dalam organisasi. Ketiga, Menyatakan perasaan dan emosi. Memberi peluang bagi para pemimpin dan anggota organisasi untuk bertukar informasi yang berkaitan dengan perasaan dan emosi. Kelima, Tindakan koordinasi. Bertujuan mengordinasikan sebagian atau seluruh tindakan yang berkaitan dengan tugas dan fungsi organisasi, yang telah dibagi habis ke dalam bagian atau sub-bagain organisasi. Organisasi tanpa koordinasi dan organisasi tanpa komunikasi sama dengan organisasi yang menampilkan aspek individual dan bukan menggambarkan aspek kerja sama.

Menurut Liliweri (2014:373) ada dua fungsi komunikasi organisasi, yakni fungsi umum dan fungsi khusus. Fungsi yang pertama adalah fungsi umum. Pertama, to tell, komunikasi berfungsi untuk menceritakan informasi terkini mengenai sebagian atau keseluruhan hal yang berkaitan dengan pekerjaan. terkadang komunikasi merupakan proses pemberian informasi mengenai bagaimana seorang atau sekelompok orang harus mengerjakan satu tugas tertentu. Contohnya, Job description. Kedua, To sell. Komunikasi berfungsi untuk "menjual" gagasan dan ide, pendapat, fakta, termasuk menjual sikap organisasi dan sikap tentang sesuatu yang merupakan subjek layanan. Contohnya public relations (humas), pameran, ekspo, dan lainlain. Ketiga, To learn. Komunikasi berfungsi untuk meningkatkan kemampuan para karyawan agar mereka bisa belajar dari orang lain (internal), belajar tentang apa yang dipikirkan, dirasakan, dan dikerjakan orang lain tentang organisasi. Keempat, To decide. Komunikasi berfungsi untuk menentukan apa dan bagaimana organisasi membagi pekerjaan, atau siapa yan menjadi atasan dan siapa yang menjadi bawahan, besaran kekuasaan dan kewenangan, menentukan bagaimana menangani sejumlah orang, bagaimana memanfaatkan sumber daya, serta mengalokasikan manusia, mesin,metode, dan teknik dalam oraganisasi. 
Fungsi yang kedua adalah fungsi khusus. Pertama, Membuat para karyawan melibatkan diri ke dalam isu-isu organisasi lalu menerjemahkannya ke dalam tindakan tertentu di bawah sebuah komando. Kedua, Membuat para karyawan menciptakan dan menangani relasi antarsesama bagi peningkatan produk organisasi. Ketiga, Membuat para karyawan memiliki kemampuan untuk menangani atau mengambil keputusan-keputusan dalam suasana yang ambigu dan tidak pasti.

\section{Komunikasi Internal Organisasi}

Menurut R. Wayne Pace dan Don F (dalam Ruliana, 2016:25) definisi fungsional dari komunikasi organisasi sebagai pertunjukan dan penafsiran pesan di antara unit-unit komunikasi yang merupakan bagian dari suatu organisasi tertentu. Suatu organisai, dengan demikian, terdiri dari unit- unit komunikasi dalam hubungan hierarki antara yang satu dengan yang lainnya dan berfungsi dalam suatu lingkungan.

Effendy (dalam Ruliana, 2016:104) menjelaskan bahwa dalam komunikasi internal organisasi dapat ditunjang dalam beberapa bentuk dimensi komunikasi. Dimensi komunikasi pertama adalah komunikasi vertikal, komunikasi vertikal dari atas ke bawah. Tommy Suprapto (dalam Batubara, 2016:81) mengatakan bahwa komunikasi kebawah dalam sebuah organisasi berarti bahwa informasi mengalir dari jabatan berotoritas lebih tinggi kepada mereka yang berotoritas lebih rendah. Aliran informasi ini biasanya disebut aliran informasi atasan kepada bawahanya. Menurut Katz dan Kahn (dalam Ruliana, 2016:104) ada lima tipe khusus komunikasi dari atas ke bawah yaitu

1. Job Instructions (instruksi kerja) yakni komunikasi yang merujuk pada penyelesaian tugas-tugas.

2. Job rationale (rasio kerja) yakni komunikasi yang memberikan pemahaman terhadap tugas dan hubungan dengan pengaturan lainnya.

3. Procedure and practice (prosedur dan pelaksanaan, yakni komunikasi tentang kebijakan-kebijakan, aturan-aturan, regulasi, dan manfaat yang ada.

4. Feedback (umpan balik), yakni komunikasi yang menghargai tentang bagaimana individu melaksanakan tugas-tugasnya dengan baik.

5. Indoctrinations of goals (doktrin atas tujuan), yakni komunikasi yang dirancang dengan karakter ideologi yang memberikan motivasi karyawan tentang pentingnya suatu misi organisasi secara keseluruhan.

Dimensi komunikasi vertikal berikutnya adalah dari bawah ke atas. Menurut Pace \& Faules (2013:189) komunikasi ke atas merupakan komunikasi di dalam suatu organisasi yang mengalir dari seseorang dengan jabatan yang lebih rendah ke jabatan yang lebih tinggi. Prinsip-prinsip yang ada di dalam program komunikasi ke atas menurut Planty dan Machaver (dalam Pace \& Faules, 2013:193) adalah:

1. Program komunikasi ke atas yang efektif harus direncanakan.

2. Program komunikasi yang efektif berlangsung secara berkesinambungan

3. Program komunikasi yang efektif menitikberatkan kepekaan dan penerimaan dalam masukan dan gagasan

4. Program komunikasi ke atas yang efektif mencakup mendengarkan secara objektif 
5. Program komunikasi ke atas yang efektif mencakup tindakan untuk menanggapi masalah

Jika dilihat dari apa saja yang harus disampaikan informasi keatas, kebanyakan analisis dan penelitian dalam komunikasi ke atas menyatakan bahwa penyelia dan manejer harus menerima informasi (Ruliana, 2016:105) yaitu berupa: Informasi yang memberitahukan apa yang dilakukan bahwa seperti laporan kerja, kemajuan, prestasi, dan laporan target rencana; Menjelaskan persoalan-persoalan kerja yang membutuhkan saran dan bimbingan dari atasanya; Memberi saran atau gagasan untuk perbaikan dalam unit-unit mereka; Mengungkapkan bagaimana pikiran dan perasaan bawahan tentang pekerjaan mereka, rekan kerja mereka dan organisasi

\section{Motivasi}

Istilah motivasi (Uno, 2011) berasal dari kata motif yang artinya adalah kekuatan yang terdapat didalam diri individu, yang menyebabkan individu tersebut berbuat dan bertindak. Motif tidak dapat diamati secara langsung melainkan diinterpretasikan dari tingkah lakunya. Menurut George dan Jones (Kartika \& Kaihatu, 2010) ada beberapa indikator motivasi. Pertama, Arah Perilaku (Direction of Behavour). Arah perilaku mengacu pada perilaku yang dipilih seseorang dalam bekerja, dari banyaknya piihan perilaku yang dapat mereka jalankan dengan baik maupun tidak. banyak contoh perilaku yang tidak tepat yang diambil olh karyawan, pilihan ini nantinya akan menjadi suatu penghambat bagi organisasi dalam mencapai tujuanya. Sedangkan, untuk mencapai tujuan perusahaan secara maksimal karyawan harus memiliki motivasi untuk dapat membantu organisasi dalam mencapai tujuanya. Diharapkan dapat bekerja tepat waktu, mengikuti peraturan yang berlaku, serta kooperatif dengan sesama rekan kerja.

Kedua, Tingkat Usaha (Level of Effort). Tingkat usaha merupakan seberapa keras usaha seseorang untuk bekerja. Dalam bekerja, seorang karyawan tidak cukup jika hanya memilih perilaku dan hanya menjalankan perilaku tersebut. Namun juga harus memiliki motivasi untuk bekerja keras dalam menjalankan perilaku tersebut. Contohnya dalam pekerjaan seorang pekerja seorang pekerja tak cukup hanya dengan datang tepat waktu namun juga perlu dilihat keseriusan dan kesunguhan dalam menyelesaikan pekerjaan.

Keempat, ingkat Kegigihan (Level of Presistence). Hal ini mengacu pada motivasi karyawan ketika dihadapkan pada suatu masalah, rintangan, atau halangan dalam bekerja, seberapa keras seorang karyawan tersebut terus berusaha menjalankan perilaku yang dipilih. Misalnya, bila ada kendala pada cuaca atau masalah kesehatan seorang karyawan, apakah karyawan tersebut tetap masuk bekerja dan sungguh-sungguh mengerjakan tugas seperti biasanya atau memilih hal lain. Dalam hal ini dibuat pengecualian jika masalah kesehatan yang dialami pekerja termasuk penyakit serius yang dapat menyebabkan seseorang tidak mampu bekerja. 


\section{METODOLOGI PENELITIAN}

Metode yang digunakan dalam penelitian ini adalah metode eksplanatif dengan pendekatan kuantitatif. Dalam penelitian ini, peneliti melakukan pengumpulan data primer melalui penyebaran kueisioner dengan jenis angket tertutup sesuai dengan populasi dan sampel yang ditentukan. Selain itu peneliti juga melakukan observasi terhadap partisipan pada saat penelitian berlangsung. Populasi dalam penelitian ini adalah Seluruh pegawai Biro Humas Kementerian Perindustrian. Sampel dalam penelitian ini adalah 57 responden Pegawai Biro Humas Kementerian Perindustrian dengan instrument penelitian yang digunakan adalah angket dengan skala jawaban yang digunakan dalam penelitian ini adalah skala likert. Adapun kisi-kisi instrument penelitian adalah sebagai berikut :

Tabel 2. Operasional Variable

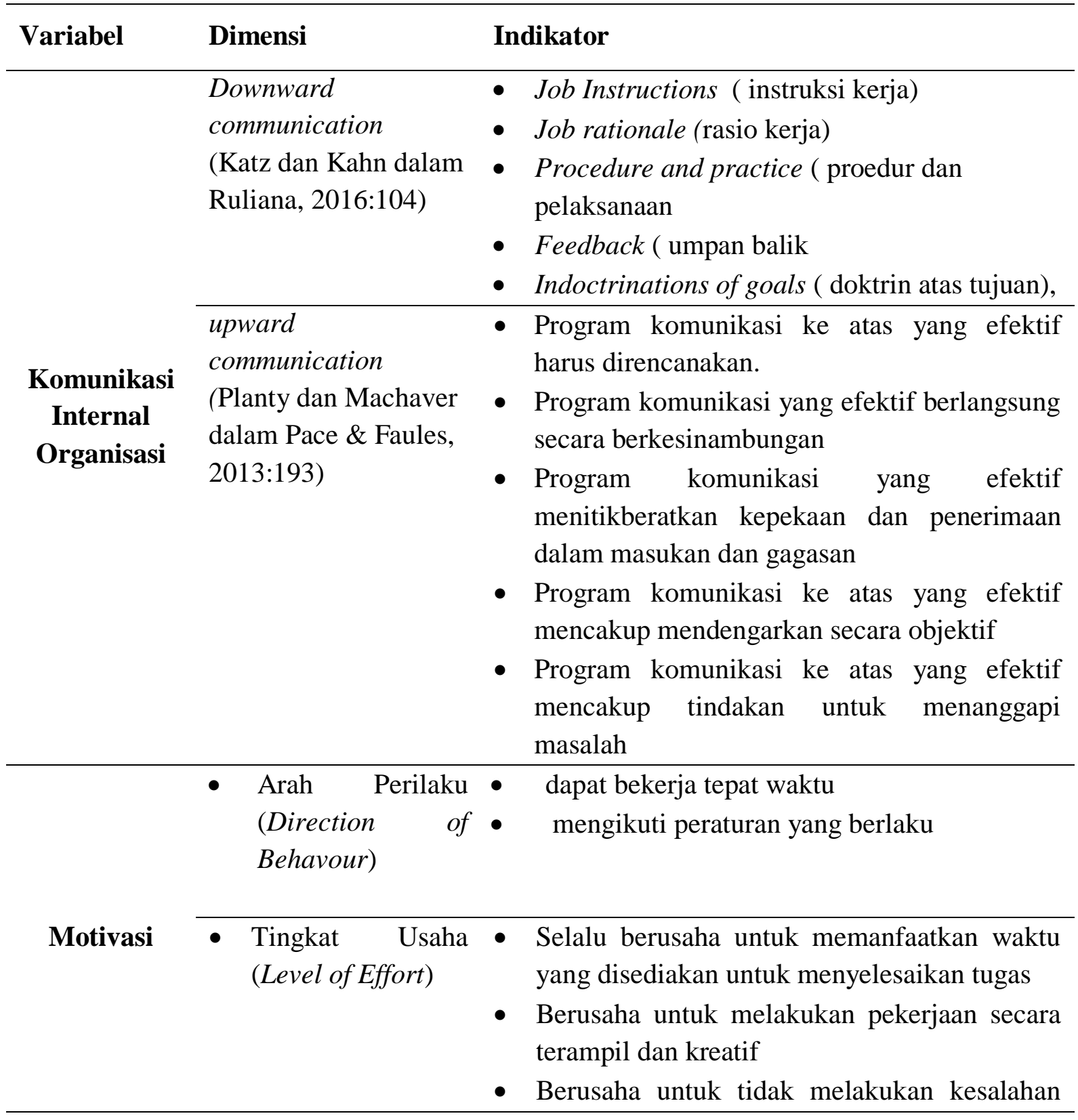


dalam bekerja

- Berusaha untuk serius dan fokus pada pekerjaan yang mereka lakukan

- Tingkat Kegigihan
(Level of
Presistence)

- Tingkat Kegigihan Presistence)
- Saat mendapat teguran dari atasan pegawai tidak berkecil hati namun justru terpacu untuk bekerja lebih baik lagi

- Setiap hasil dari pekerjaan yang dilakukan karyawan sudah sesuai dengan standard yang ditetapkan

Sumber : Data olahan peneliti, 2017

Sebelum instrument disebar kepada responden, peneliti memandang perlu melakukan uji coba terlebih dahulu dengan melakukan uji validitas dan reabilitas. Setelah data terkumpul maka peneliti melakukan analisa data dengan Uji Instrument penelitian ( uji validitas dan Uji Reabilitas), Uji Asumsi Klasik menggunakan uji normalitas, uji korelasi, uji koefisien determinasi, analisis uji regresi sederhana, dan uji hipotesis.

\section{HASIL DAN PEMBAHASAN}

Berdasarkan kuesioner yang telah di sebarkan maka dapat terlihat bahwa pada variable komunikasi internal yang perlu lebih diperhatikan pada komunikasi internal dari bawahan ke atasan pada biro humas kementerian perindustrian mereka jarang melakukan rapat rutin dalam membicarakan pekerjaan di masa mendatang hal itu terlihat pada pernyataan "karyawan biasanya melakukan rapat lebih dairi tiga kali dalam satu bulan untuk membicarakan pekerjaan yang saat ini dikerjakan maupun yang akan datang terlihat bahwa responden sebesar 3,5\% menjawab sangat tidak setuju, 7\% menjawab tidak setuju, 31,6\% menjawab ragu-ragu. Namun pendapat responden mengenai pernyataan "karyawan tidak ragu untuk menyampaikan aspirasi saya mengenai hal-hal yang berhubungan dengan pekerjaan maupun hal yang berkaitan dengan kemajuan organisasi" terlihat bahwa sebagian besar responden dengan persentase $54,4 \%$ menjawab setuju, dan $15,8 \%$ menjawab sangat setuju. Dimana hal itu merupakan hal yang baik karena menurut Ruliana (2016, p. 105) informasi yang dibutuhkan manajer atau penyelia salah satunya adalah pengungkapan pikiran dan perasaan bawahan mengenai pekerjaan mereka, rekan kerja mereka, dan organisasi. Dengan penyampaian inspirasi diharapkan bahwa dapat membuat para karyawan melibatkan diri kedalam isu-isu organisasi lalu menerjemahkannya ke dalam tindakan tertentu dalam peningkatan kualitas daripada Biro Humas Kementerian Perindustrian

Pada variable motivasi pendapat responden mengenai kuesioner yang berisi pernyataan "pada saat karyawan mendapat teguran dari atasan, mereka tidak berkecil hati tetapi justru semakin terpacu untuk bekerja lebih baik lagi" terlihat bahwa responden dengan persentase sebesar 52,6\% menjawab setuju, dan 24,6\% menjawab sangat setuju. Menurut Sutrisno (2009, p. 118) karyawan akan dapat merasa puas dalam melakukan pekerjaan jika diberikan kesempatan untuk memperoleh umpan balik dari hasil pekerjaan yang telah dilakukan. Dengan memberikan teguran maupun penghargaan itu sendiri dapat memicu motivasi kerja 
yang ada dalam diri pegawai sehingga dapat bekerja lebih baik lagi. Kemudian pendapat responden mengenai pernyataan "Pada saat karyawan melakukan pekerjaan, mereka akan berinisiatif sendiri untuk langsung memperbaiki dirinya menjadi lebih baik" juga terlihat bahwa responden dengan persentase sebesar, 56,1\% menjawab setuju, dan 15,8\% menjawab sangat setuju. Hal tersebut merupakan respon yang baik karena berkaitan dengan tanggung jawab di sebuah instansi (Sutrisno, 2009, p. 120) dengan diberikan pekerjaan dapat membuat seorang karyawan merasa diberi kepercayaan untuk melakukan kegiatan yang merupakan dorongan untuk memenuhi kebutuhan sense of achievement dalam tugas sehari-hari. Berinisiatif untuk melakukan hal yang lebih baik lagi merupakan sikap yang dimiliki oleh seorang pekerja yang memiliki motivasi kerja yang tinggi.

\section{Uji Validitas dan Reabilitas}

Setelah peneliti mempersiapkan kuesioner yang memuat sejumlah pernyataan maka peneliti menyebarkan kuesioner tersebut kepada 57 pegawai Biro Humas Kementerian Perindustrian. Menurut Neuman (2016:238) validitas adalah keabsahan atau akurasi suatu alat ukur. Validitas memastikan informasi yang didapat merupakan informasi yang bekualitas sesuai dengan realita. Dalam melakukan uji validitas pada penelitian ini derajat kebebasan atau degree of freedom ( $\mathrm{df}$ ) menggunakan rumus $\mathrm{df}=\mathrm{N}-2$. Maka hasil yang di peroleh adalah 55 sehingga nilai $r$ hitung yang di dapat adalah 0,2609 . Setelah peneliti mendapatkan hasil kuesioner yang di bagikan kepada 57 pegawai. Maka hasil pengujian vaiditas dari 57 responden Berdasarkan hasil pengujian validitas dengan SPSS diatas, terlihat dari 22 pernyataan yang diajukan dalam kuesioner untuk mewakili variable komunikasi Internal (X) dan variable Motivasi (Y), nilai "corrected item-total correlation" atas semua pernyataan bernilai diatas 0,2609 yang berarti seluruh pernyataan yang mewakili variable komunikasi Internal (X) dan Variable Motivasi (Y) dinyatakan valid.

Reliabilitas (Neuman, 2016:234) berarti kemampuan untuk diandalkan atau konsistensi. Reliabilitas berarti bahwa hasil numeric yang dihasilkan oleh indikator tidak bervariasi karena karateristik dari proses pengukuran itu sendiri. diketahui bahwa nilai cronbach's alpha untuk Variabel komunikasi internal organisasi (X) sebesar 0,837 dan untuk variable motivasi (Y) sebesar 0,928 yang mana lebih besar dari 0,60. Maka dapat ditarik kesimpulan bahwa pada variable komunikasi internal organisasi $(\mathrm{X})$ dan variable motivasi (Y), kuesioner yang di sebar dapat diandalkan atau dipercaya karena dapat menghasilkan jawaban responden yang relatif konsisten. 
Normal P-P Plot of Regression Standardized Residual

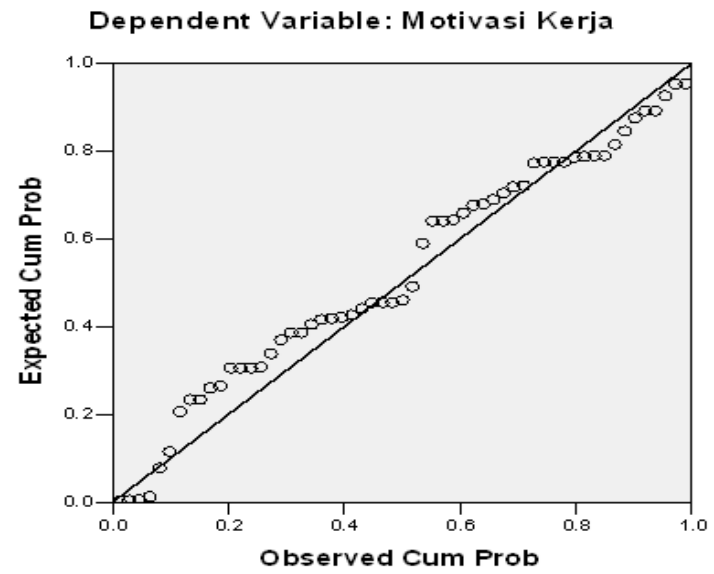

\section{Gambar 1. Hasil Uji Normalitas}

Uji normalitas (Hamdi \& Bahruddin, 2014, p. 113) bertujuan untuk meguji apakah data penelitian yang diteliti memiliki distribusi normal yang baik. Gambar 1 memperlihatkan hasil uji normalitas yang mana menunjukan bahwa titik-titik tersebar di sekitar garis diagonal dan penyebaranya mengikuti mendekati garis diagonalnya, dimana hal ini menunjukkan bahwa data pada penelitian ini terdistribusi secara normal. Hal tersebut menunjukan bahwa pernyataan-pernyataan yang diajukan dalma kuesioner terdistribusi secara normal.

Tabel 3. Hasil Uji Korelasi Variabel X dan Y

\begin{tabular}{llcc}
\hline & & $\begin{array}{c}\text { Komunikasi Internal } \\
\text { Organisasi }\end{array}$ & Motivasi \\
\hline $\begin{array}{l}\text { Komunikasi Internal } \\
\text { Organisasi }\end{array}$ & Pearson Correlation & 1 & 0.748 \\
\cline { 2 - 4 } & Sig. (2-tailed) & 57 & 0.000 \\
\cline { 2 - 4 } & $\mathrm{N}$ & 57 \\
\hline Motivasi & Pearson Correlation & 0.748 & 1 \\
\cline { 2 - 4 } & Sig. (2-tailed) & 0.000 & 57 \\
\cline { 2 - 4 } & $\mathrm{N}$ & 57 & 57 \\
\hline
\end{tabular}

**. Correlation is significant at the 0.01 level (2-tailed).

Uji korelasi digunakan untuk mencari tahu hubungan antara dua variabel dan seberapa signifikan hubunganya. Hasil uji korelasi menunjukan hasil signifikansi 0,000 yang lebih kecil dari 0,05. Hal ini memperlihatkan bahwa hubungan kedua variabel positif dan cukup kuat berdasarkan nilai pearson correlation sebesar 0,748 . 
Tabel 4. Hasil Uji Koefisien Determenasi

Model Summary

\begin{tabular}{ccccc}
\hline Model & R & R Square & $\begin{array}{c}\text { Adjusted R } \\
\text { Square }\end{array}$ & $\begin{array}{c}\text { Std. Error of } \\
\text { the Estimate }\end{array}$ \\
\hline 1 & 0.748 & 0.560 & 0.552 & 0.38260 \\
\hline
\end{tabular}

a. Predictors: (Constant), Komunikasi Internal Organisasi

Besarnya koefisien determinasi adalah 0,560 atau 56\% sehingga dapat disimpulkan bahwa pengaruh komunikasi internal terhadap motivasi kerja karyawan memberikan kontribusi pengaruh sebesar 56\% sedangkan $44 \%$ lainya dipengaruhi oleh faktor-faktor lain yang tidak berada dalam ruang lingkup ini.

Tabel 5. Hasil Uji Regresi Variabel X dan Y

Coefficients(a)

\begin{tabular}{clccccc}
\hline Model & & $\begin{array}{c}\text { Unstandardized } \\
\text { Coefficients }\end{array}$ & & $\begin{array}{c}\text { Standardized } \\
\text { Coefficients }\end{array}$ & $\mathrm{t}$ & Sig. \\
\hline & $\mathrm{B}$ & $\begin{array}{c}\text { Std. } \\
\text { Error }\end{array}$ & Beta & & \\
\hline 1 & (Constant) & 0.509 & 0.417 & & 1.220 & 0.228 \\
\hline & $\begin{array}{l}\text { Komunikasi } \\
\text { Internal Organisasi }\end{array}$ & 0.922 & 0.110 & 0.748 & 8.360 & 0.000 \\
\hline
\end{tabular}

a. Dependent Variable: Motivasi Kerja

Analisis regresi liner sederhana (Suyono, 2015) merupakan model yang menyatakan hubungan linier antar dua variabel dimana salah satu variabel dianggap mempengaruhi variabel yang lain. Adapun persamaan regresi linier sederhana pada penelitian ini, yaitu :

$$
\mathrm{Y}=0,509+0,922 \mathrm{X}
$$

Dari persamaan regresi sederhana diatas, dapat dijelaskan bahwa koefisien regresi variable komunikasi internal (X) adalah sebesar 0,922 yang artinya jika nilai variabel komunikasi internal mengalami kenaikan 1 satuan, maka nilai dari motivasi kerja akan mengalami kenaikan sebesar 0,922. Begitu pula sebaliknya, jika variable komunikasi internal mengalami penurunan 1 satuan maka nilai dari variabel motivasi kerja akan mengalami penurunan sebesar 0,535 . 
Tabel 6. Hasil Rangkuman Uji Hipotesis

Coefficients(a)

\begin{tabular}{clccccc}
\hline Model & & $\begin{array}{c}\text { Unstandardized } \\
\text { Coefficients }\end{array}$ & & $\begin{array}{c}\text { Standardized } \\
\text { Coefficients }\end{array}$ & $\mathrm{t}$ & Sig. \\
\hline & $\mathrm{B}$ & $\begin{array}{c}\text { Std. } \\
\text { Error }\end{array}$ & Beta & & \\
\hline 1 & (Constant) & 0.509 & 0.417 & & 1.220 & 0.228 \\
\hline & $\begin{array}{l}\text { Komunikasi } \\
\text { Internal Organisasi }\end{array}$ & 0.922 & 0.110 & 0.748 & 8.360 & 0.000 \\
\hline
\end{tabular}

a. Dependent Variable: Motivasi Kerja

Uji Hipotesis (Sudaryono, 2017:358) merupakan uji yang digunakan untuk mengetahui ada atau tidaknya pengaruh yang signifikan . Penentuan formula hipotesis sebagai berikut :

Ho: Variabel independen secara parsial tidak berpengaruh secara signifikan terhadap variabel dependen.

Ha: Variabel independen secara parsial berpengaruh terhadap variabel dependen.

Kriteria pengujian yang ada dalam uji hipotesis ini adalah sebagai berikut :

a. Jika nilai probabilitas > 0,05 maka Ho diterima. Yang berarti variabel independen secara parsial tidak bepengaruh terhadap variabel depeden.

b. Jika nilai probabilitas $<0,05$ maka Ha diterima. Yang berarti bahwa variabel independen secara parsial berpengaruh terhadap variabel dependen.

Dari hasi uji diperoleh bahwa pengaruh secara parsial dari variabel komunikasi internal organisasi (X) terhadap variabel Motivasi kerja karyawan pegawai Biro Humas Kementerian Perindustrian (Y) melalui nilai Sig. yang menunjukkan angka 0.000, dimana 0.000 lebih kecil daripada $0.05(0.00<0.05)$. Maka dapat disimpulkan bahwa Ha diterima dan Ho ditolak. Artinya, adanya pengaruh komunikasi internal organisasi terhadap motivasi kerja pegawai Biro Humas Kementerian Perindustrian.

\section{PENUTUP}

Terdapat pengaruh komunikasi internal organisasi antara Kabid dan Staff terhadap motivasi kerja pegawai biro humas Kementerian Perindustrian dan presentase kontribusi komunikasi internal adalah sebesar 56\% sedangkan $44 \%$ dipengaruhi oleh faktor lain yang tidak berada dalam ruang lingkup penelitian ini. Berdasarkan hasil penelitian mengenai pengaruh komunikasi internal organisasi terhadap motivasi kerja pegawai, Peneliti bermaksud memberikan rekomendasi yang mudah-mudahan dapat bermanfaat bagi lembaga maupun bagi peneliti selanjutnya yaitu sebagai berikut Berdasarkan hasil temuan pada penelitian bahwa pegawai di dalam biro humas kementerian bagi pegawai hendaknya memberi perhatian lebih tehadap absensi. Berdasarkan data absensi periode September 2017 sampai dengan desember 2017 masih ada sekitar 30\% pegawai yang datang terlambat. Maka 
bagi pegawai Biro Humas Kementerian Perindustrian disarankan untuk datang lebih tepat waktu agar kinerja yang dihasilkan bisa lebih maksimal, dan diharapkan Bagi Biro Humas Kementerian Perindustrian hendaknya lebih banyak mengadakan program bagi pegawai Biro Humas Kementerian Perindustrian agar hubungan antara pegawai bisa lebih dekat.

\section{REFERENSI}

\section{Buku penulis tunggal:}

Kaswan. (2008). Psikologi Industri dan Organisasi. Bandung: Alfabeta.

Liliweri, A. (2011). Komunikasi Serba Ada Serba Makna. Jakarta: Kencana Prenada edia Group

Neuman, W. L. (2016). Metodologi Penelitian Sosial : Pendekatan Kuantitatif dan Kualitatif. Jakarta: Indeks.

Ruliana, P. (2016). Komunikasi Organisasi Teori dan Kasus. Depok: PT RAJAGRAFINDO PERSADA.

Sudaryono. (2017). Metodologi Penelitian . Depok: PT RAJAGRAFINDO PERSADA.

Sutrisno, E. (2009). Manajemen Sumber Daya Manusia. Jakarta: KENCANA

Suyono. (2015). Analisis Regresi Untuk Penelitian. Yogyakarta: Deepublish.

Uno, H. (2011). Teori Motivasi dn Pengukurnya. Jakarta: Bumi Aksara

Buku dengan dua sampai tujuh penulis:

Hamdi, A. S., \& Bahruddin, E. (2014). Metode Penelitian Kuantitatif Aplikasi Dalam Pendidikan. Yogyakarta: Deepublish.

Pace, R., \& Faules, D. (2013). Komunikasi Organisasi Strategi Meningkatkan KInerja Perusahaan. Bandung: PT Remaja Rosdakarya

\section{Artikel Jurnal:}

Astuti, I. M., Bagia, I. W., \& Susila, G. A. (2016). Pengaruh Komunikasi Internal dan Budaya Organisasi Terhadap Kepuasan Kerja Karyawan. e-Journal Bisma Universitas Pendidikan Ganesha, 4.

Ariyani, D. K. (n.d.). Pengaruh Budaya Organisasi, Motivasi, Kepuasan Kerja Terhadap Kinerja Karyawan Karyawan pada PT. Mandalatama Armada Motor Semarang . Jurnal Penelitian Ekonomi dan Bisnis .A5

Batubara, A. K. (2016, Mei). Aliran Informasi dalam Organisasi Perpustakaan. Jurnal Iqra', 10.

Effendi, h. (2016, April). Pengaruh Intellectual Capital dan Komunikasi Organisasi terhadap Efektivitas Implementasi Renstra UPI. Jurnal Administrasi Pendidikan, XXIII, 27.

Kartika , E. W., \& Kaihatu, T. (2010). Analisis Pengaruh Motivasi Kerja Terhadap Kepuasan Kerja. Jurnal Manajemen dan Kewirausahaan, 12, 103. 
Mokodompit, F. (2013). Pengaruh Komunikasi Organisasi Terhadap Efektivitas Kinerja Pada PT. Radio Memora Anoa Indah. Acta Diurna, 3.

Sari, I., \& Nurdin. (2016). Pengaruh komunikasi Internal Terhadap Kinerja Pegawai. Jurnal Administrasi Pendidikan, XXIII, 92.

Usman, B. (2013, April). Pengaruh komunikasi Interpersonal terhadap Kinerja Pegawai Pada Fakultas Ekonomi Universitas PGRI Palembang. Jurnal Media Wahana Ekonomika, 1, 1.

\section{Dokumen resmi:}

Badan Pusat Statistik. (n.d.). Badan Pusat Statistik. Retrieved May 11, 2018, from Data Sensus Tenaga kerja: https://www.bps.go.id/subject/6/tenaga-kerja.html

Kementerian Perindustrian. (n.d.). Kementerian Perindustrian. Retrieved 9 28, 2017, from Tugas Pokok dan Fungsi Kementrin Perindustrian: http://kemenperin.go.id

Kementerian Perindustrian. (n.d.). Kementerian Perindustrian Republik Indonesia. Retrieved November 5, 2017, from Permenperin 107: www.kemenperin.go.id/download/11683 